\title{
Does Trade Liberalization Cause Long Run Economic Growth in Mexico? An Empirical Investigation
}

\author{
Olajide S. Oladipo \\ Department of Business and Economics \\ School of Business and Information Systems, York College/CUNY - United States \\ E-mail: ooladipo@york.cuny.edu
}

Received: November 18, 2010

Accepted: December 21, 2010

doi:10.5539/ijef.v3n3p63

\begin{abstract}
Mexico, in its quest for economic growth, moved from an import substituting inward-oriented policy regime towards an outward oriented trade regime since the introduction of the economic reform in 1985. In the form of stocktaking, this study examines the impact of trade liberalization (openness) on long run economic growth in Mexico by using data from 1980:q1 to 2008:q4 with the help of cointegration and error correction methods. The empirical results suggest that long run economic growth in Mexico is largely explained by trade liberalization (openness) and the level of capital (investment). The results, however, show that the contribution of labor force and human capital is minimal. This is somewhat surprising given increased educational spending over the last decade. The estimated coefficient of the ECM indicates low speed of adjustment to equilibrium. The sign of the ECM term is negative and significant, thus, confirming that the system corrects its previous period's disequilibrium by 20 percent a quarter.

The policy implication of our results is that Mexico needs to intensify trade and investment reforms to promote sustainable long run economic growth. As an open economy, Mexico should continue to avoid real exchange rate overvaluation while minimizing exchange rate volatility. There is also the need to complement reforms in trade and investment sectors with reforms in the education sector.
\end{abstract}

Keywords: Trade liberalization (openness), Economic growth, Cointegration, Mexico

JEL Classification: F14, F43, O24

\section{Introduction}

For some decades, Mexico pursued economic development via import substitution industrialization (ISI), a development strategy pioneered by the Economic Commission for Latin America (ECLA) under Raul Prebisch and supported by the theoretical thinking of Hans Singer (1950) and Myrdal (1957). During this period, many developing countries equated industrialization with development, and as a result, ISI was eagerly pursued. However, the experience of many East Asian countries revealed that the ISI strategy is not a panacea for the problem of underdevelopment. Early empirical studies by Little, Scitovsky and Scott (1970), Krueger (1978) and Bhagwati (1978) among others demonstrated that the ISI strategy often led to overvaluation of exchange rate resulting in a detrimental impact on the balance of payments.

Therefore, after three decades of ISI policies, and coupled with the consequences of high inflation and debt crisis, Mexico embarked on trade liberalization. In 1985, the economic role of the government was reduced by selling off most public enterprises, and completely deregulating major sectors of the economy such as transportation, telecommunications, and financial institutions. The process also included removing the lid on the economy to allow for foreign capital flows, elimination or substantial reduction of tariffs, gradually rescinding import licenses while export promotion policies were pursued, particularly through the maquiladoras sector (Note 1). Beginning with its membership of the General Agreement on Tariffs and Trade (GATT) in 1986, Mexico has signed more trade agreements than any other country in the world. In 1994, Mexico joined the Organization for Economic Cooperation and Development (OECD) and that same year, the North American Free Trade Agreement (NAFTA) came into effect. (Note 2)

The traditional economic theory predicted that liberalization will result in increased trade, accelerate technological change, improve efficiency gains and enhance economic growth. Of course, one of the main selling points of trade liberalization to the developing countries is the belief that labor would benefit since the production of export was believed to be more labor-intensive than production for internal market. With the introduction of trade reforms in many developing countries in the late 1980s and early 1990s, a considerable number of time series studies have been 
conducted on the impact of export trade on economic growth (see Edwards, 1993; World Bank, 1993; Ghatak et al 1995; Salinas and Aksoy, 2006) to name a few. For Mexico, studies of this nature are often cross-sectional (Dutt and Ghosh 1996; Krishna, Ozyildirim and Swanson 2003; Mainkhel, Thangavelu and Kalirajan 2009) with the exception of (Ten Kate 1992; Pastor 1994). The results of the various cross sectional studies on Mexico as well as the 'new' growth literature suggest that their conclusion cannot be generalized. There is need for more country-specific studies on the subject matter to shed more light on the debate and allow for country-specific policies.

Following the introduction, section two discusses the proximate impact of trade liberalization policy on Mexican exports and imports. Section three contains a brief review of the literature, while the analytical methods and the empirical findings are presented in sections four and five. Section six contains the conclusion and policy recommendations.

\section{Proximate Impact of Trade Liberalization Policy on Exports and Imports in Mexico}

Trade liberalization has its roots in classical trade theory which argues that free trade promotes economic efficiency and facilitates economic growth through its dynamic effects on exports. In realization of the perceived benefits, Mexico in 1985 abandoned the ISI and the state led industrialization strategy for a development strategy that centered on trade liberalization and drastic reduction in government's intervention in the economy.

Mexico joined the OECD, the World Trade Organization (WTO) and signed free trade agreements (FTAs) with numerous countries. Mexico's pursuit of FTAs with other countries is not only perceived to provide economic benefits, but it was envisaged that it would reduce its economic dependence on the United States. In an effort to increase trade with other countries, Mexico has a total of 11 trade agreements involving 41 countries. These include agreements with most countries in the Western Hemisphere such as the United States and Canada (1994), Costa Rica (1995), Nicaragua (1998), Chile (1999), Guatemala (2001), El Salvador (2001), and Honduras (2001). In addition, Mexico negotiated FTAs outside the Western Hemisphere with Israel (2000), European Union (2000) and Japan (2005) (Note 3). However, the large number of trade agreements has not decreased Mexico's dependence on trade with the United States. Currently, Mexico's export to the United States is 80 percent of her total exports while her import is 49 percent.

An attempt to complement these FTAs led President Zedillo (1994-2000) to launch the industrial and foreign trade programs which contain sector-specific policies and incentives to increase domestic value added in the priority sectors that include textile, footwear, automobile, electronics, appliances, steel, petrochemicals and canned foodstuff production. With these reforms, Mexico has been able to increase her exports of non-oil products. Mexico is also one of the few countries that have successfully increased her share of world market for non-oil exports, most especially manufactured products. As depicted in panel A of Table 1, between 1985 and 1994, Mexico occupied the fifth position in the world among countries with the largest increase in their share of world exports of manufactures. Of course, a cursory observation revealed that between 1994 and 2004, it ranked in second place after China.

\section{Insert Table 1 Here}

Panel B of Table 1 shows the total value of exports of manufactures in the world. From the list of countries, Mexico ranks among countries whose total value of exports has increased tremendously between 1995 and 2004. Mexico moved from $10^{\text {th }}$ position in 1985 to $5^{\text {th }}$ position with an absolute increase of US $\$ 92$ billion in exports of manufactured. An important characteristic of Mexican export is the increasing participation of the maquiladoras. The Maquiladoras activity on average account for more than 50 percent of total manufacture exports products. In 2006, 81 percent of the apparel exports, 78 percent of the plastic products exports, 84 percent of electric machinery and electronic exports (including computers, TV, etc. and its parts), 72 percent of the transport industry (including automobiles and auto-parts) exports came from the maquiladoras industry (Note 4).

Figure 1 below revealed Mexico's composition of exports which is classified into (agriculture, and manufactures) non-oil and oil exports for ease of analysis. Of course, Mexico's export boom in manufactures coincided with the implementation of trade liberalization. Figure 1 revealed a huge increase in manufacture in 1986 but Mexico witnessed sustained increases just before NAFTA agreement. Thus, there is no doubt that NAFTA enhances the process by providing Mexico uninhibited access to United States, the largest market in the world.

\section{Insert figure 1 Here}

Before the NAFTA agreement, the share of total exports in real gross domestic product which was 16 percent increased to 35.1 percent by 2000 (more than doubled). According to Moreno-Brid et al (2005), the spectacular performance of the export sector can be linked to three major factors. First, the collapse of Mexico's domestic market in 1995 which indirectly forced most firms to embark on export drive so as to compensate for decline in sales. Second, the continuous depreciation of exchange rate of peso against the US dollar but this has been gradually 
eliminated with the appreciation of peso to dollar since 2006. Third, the increase in the number of foreign firms with established subsidiaries in Mexico as a result of trade reforms, NAFTA and the privatization of public enterprises. Mexico currently enjoys huge inflows of foreign direct investment (FDI) from about 2 percent of GDP in 1990s to 8 percent in 2007.

Irrespective of the FTAs with many countries, the percentage of Mexico's export destined for and imports received from NAFTA trading partners still remained very high. The percentage of exports increased from 85 percent in 1996 to 90 percent in 2002, and then decreased in the following years as shown in panel A of Table 2.

\section{Insert Table 2 Here}

On the other hand, exports to the European Union is relatively stable at an average of 3.5 percent between 1996 and 2006 but accounted for 6 percent of Mexico's total exports in 2008. As reported in panel B of Table 2, the share of Mexico's imports from NAFTA trading partners decreased from 77 percent in 1996 to 52 percent in 2008. In another vein, Mexico's imports from the European Union increased from 9 percent in 1996 to 13 percent in 2008 while the share of non-FTA countries increased from 8 percent to 28 percent. In 2008, Mexico's imports from Japan accounted for 5 percent while imports from Chile and other FTA partners were 3 percent.

\section{Literature Review}

Trade openness can be perceived as synonymous with the idea of neutrality in trade policy. Neutrality implies that incentives are equal between saving a unit of foreign exchange through import substitution and earning a unit of foreign exchange through exports (Note 5). Trade liberalization is regarded as a process of moving away from quota restrictions, at possibly, disequilibrium exchange rates to one where only tariffs are used at equilibrium exchange rate (Bhagwati and Krueger, 1978). It can be regarded as any change which leads a country's trade system towards neutrality in the sense of bringing its economy closer to the situation which would have prevailed if there were no governmental interference (Papageorgiou, Michaely, and Choksi, 1990). Martin (1992) opines that a trade regime is seen as "open" if it is discovered to be neutral in an average sense when it is non-neutral in respect of specific sectors. Therefore, trade reform increases openness through a shift towards greater neutrality by decreasing inequality in the average incentives. The reduction can be achieved by either reducing import protection and export restrictions or by raising export incentives. However, it is more desirable to drive neutrality through reductions in import protection and export restrictions.

Some empirical studies have confirmed a positive openness performance link for developing countries. The study by Little, Scitovsky and Scoot (1970) is the pioneering modern multi-country investigation on trade orientation and economic performance in the developing countries. The most important contribution of these studies is that they provide comparative evidence on how the structure of protection to intermediate and final goods affected relative profitability to sector value added. This was done by computing Effective Rates of Protection (ERPs) for each of the countries. They observed that the degree of protection granted to manufacturing value added was significantly higher than suggested by straightforward data on nominal import tariffs. Thus, they infer that the policies adopted in most of the developing world had excessively encouraged industrialization at the cost of reducing the incentives for expanding agriculture and exports. The consequences of this protectionist policy had been a worsening of income distribution, reduction in savings and very low capacity utilization. The main policy recommendation from these studies was that the developing countries should greatly reduce the degree of protection, and open up to international competition.

Streeten (1971) criticized the study by Little et al. and Balassa (1970) on the ground that no serious effort was made at analyzing liberalization episodes. Second, neither Little et al. nor Balassa ventured into the analysis of how specific countries evolved from one trade regime to another, nor did they investigate empirically and in detail how alternative policies had affected growth in particular historical settings. They concentrated their investigations on the characteristics of the import substitution regime, without comparing it with alternative ways of organizing the external sector. Krueger (1978) and Bhagwati (1978) provide the first systematic attempt at formally classifying trade regimes. In order to evaluate the effect of trade policies, Krueger and Bhagwati identified five phases in the evolution of trade regimes. Using data from the individual country studies, Krueger's econometric analysis revealed that there exists a strong evidence in favor of an indirect effect of liberalization on growth; higher exports positively affect GNP growth. However, the dummy variables coefficients were not significant in any of the regressions estimated suggesting that there is no direct effect of liberalization on growth. The conclusion that trade regime per se had no direct effect on economic performance prompted further research effort. Balassa (1982) argued that Krueger's results were seriously affected by inadequate classifications of trade regimes. According to him, Krueger focused exclusively on quantitative restrictions (QRs) and thus ignored the protective effect of tariffs. He pointed out that even in the absence of QRs, high tariffs usually introduced a strong bias against export. He thus, proposed 
an alternative way of classifying trade regimes. This ranged from outward (where the export bias stemming from QRs and tariffs had been eliminated) to inward orientation where the anti-export bias was the highest.

Edwards (1989) using an extensive cross-country data set, observed that, if nominal devaluations are accompanied by a set of consistent macro-economic policies, it is possible to generate significant real exchange rate devaluation and thus, reductions in the trade system anti-exports bias. In his analysis of thirty-nine major devaluation episodes in the developing countries between 1962 and 1982, Edwards found that in twenty-five out of thrity-nine cases the nominal exchange rate adjustment succeeded in significantly altering the real exchange rate. Additionally, he found that in the vast majority of these cases, the successful devaluation package had been accompanied by major steps towards dismantling trade, capital and exchange controls. In every one of these cases, exports experienced a rebound and the overall external position of the country experienced a significant improvement relative to its predevaluation level.

In the same vein, a survey of literature by Winters (2004) on trade liberalization and economic growth, he concluded that despite methodological challenges and disagreements about the strength of the evidence, the most plausible conclusion is that liberalization generally induces a temporary increase in growth. He further stressed the importance of other factors such as investment and institutions in the growth process and argued that these factors respond positively to trade liberalization. Also, studies by Amsdein (1989), surveys by Perkins and Roemer (1994), Ghatak et al. (1995), Dollar and Kraay (2004), Salinas and Aksoy (2006) and World Bank (2007) are instructive of the role of openness in the growth process in developing countries.

On the other hand, trade liberalization may also have negative impacts on growth. As posited by Grossman and Helpman (1991) and Srinivasan (2001), the endogenous growth model suggests that trade may be growth stunting. Trade openness exposes developing countries to volatility of output and terms of trade. Rodriguez and Rodrik (2001) argue that the measures of trade openness used in many studies showing positive links between trade liberalization and exports are flawed. They argue that if the magnitude of shocks is beyond the absorptive capacity of the country, the forces of dynamic comparative advantage push the economy away from the direction of activities that stimulate long run economic growth. They concluded that there is little evidence that lower tariff and non-tariff barriers to trade have strong correlation with economic growth.

Hanson and Harrison (1999) opine that most findings are dependent on the measure of openness and model specification. They argue that Sachs and Warner (1995) fail to establish a robust link between more open trade policies and long run growth. Furthermore, Greenaway el al. (1998) conclude that trade liberalization resulted in both an increase and decrease in growth rate depending on country circumstances. In a survey of 19 developing countries, Papageorgiou et al. (1991) found that trade liberalization resulted in more rapid growth of exports, more rapid growth of GDP and it accomplishes this without serious transitional costs in unemployment and without significant effects on the government's fiscal position.

Some studies have investigated the export-growth nexus for Mexico. Dutt and Ghosh (1996) in a cross section analysis examined the causal relationship between export and economic performance. Their result for Israel and Mexico confirmed a positive relationship between export and economic growth while others such as Pakistan did not. In the same vein, Krishna, Ozyildirim and Swanson (2003) found that for two thirds of the countries examined including Mexico (twenty five in all), growth is best explained by exports and/or imports. Mainkhel, Thangavelu and Kalirajan (2009) employed a time series framework of the vector error correction models to study the relationship among exports, FDI and GDP growth for six emerging countries of Chile, India, Mexico, Malaysia, Paksitan and Thailand. They found that in South Asia, there is evidence of an export led growth hypothesis. However, in the long run, they identified GDP growth as the common factor that drives growth in other variables such as exports in the case of Pakistan and FDI in the case of India. The Latin American countries of Mexico and Chile show a difference of relationship in the short run but in the long run, exports affect the growth of FDI and output. They found bidirectional causality between GDP and FDI in Thailand while no relationship was found between these variables in the case of Malaysia.

A common feature of most of the earlier studies is that most relied on international cross sectional evidence. Many of these studies regress a growth variable on a contemporaneous export variable. The problems associated with these studies are well known. One important limitation of the method is the assumption that the coefficients of parameter estimates are similar across countries which may not be true for some countries chosen in the sample (Edwards, 1993). Also, some paid little attention to the time series properties of the data.

The debate is no longer so much on whether trade or sheer export orientation will lead to growth but given the spate of reforms in most developing countries in the 1980s and early 1990s, a major component of which is trade 
liberalization, whether reform measures that emphasize openness can indeed contribute to economic growth in developing countries using Mexico as a case study. We find scanty evidence of this for the Mexican economy.

\section{Model Specification and Sources of Data}

The aggregate production function is employed in the study to estimate the openness - performance link. Let the country's aggregate production function be defined as:

$$
Y=Y[(K, L, H) ; A]
$$

where $\mathrm{Y}$ is the real aggregate output, $\mathrm{K}$ is the physical capital, $\mathrm{L}$ is labour, $\mathrm{H}$ is human capital and $\mathrm{A}$ is the productivity or efficiency parameter assumed to be a function of degree of openness $\left(T_{0}\right)$. Hence:

$$
Y=Y\left[(K, L, H) ; A\left(T_{0}\right)\right]
$$

where $A=A\left(T_{0}\right)$. Thus, the growth of output is a function of the capital stock, human capital and the labour force. The measure of openness $\left(T_{0}\right)$, which is a policy variable, also contributes to output. Expressing the equation is growth terms, we differentiate equation (2) totally and obtain:

$$
d Y=Y_{K} d K+Y_{L} d L+Y_{H} d H+Y_{T_{0}} d T_{0}
$$

where $Y_{i}$ is the partial derivative of $Y$ with respect to its argument in equation (1). Equation (3) indicates that the level of real aggregate output $(Y)$ can be higher with the same capital, labour and human capital inputs if productivity is higher due to a greater degree of openness. That is, $Y_{T_{0}}>0$. Dividing equation (3) by $Y$ and re-arranging terms, we have:

$$
\frac{d Y}{Y}=e_{K} \frac{d K}{K}+e_{L} \frac{d L}{L}+e_{H} \frac{d H}{H}+e_{T_{0}} \frac{d T_{0}}{T_{0}}
$$

where $\frac{d Y}{Y}, \frac{d K}{K}, \frac{d L}{L}, \frac{d H}{H}$ and $\frac{d T_{0}}{T_{0}}$ are the rates of change of output, capital, labour, human capital and trade policy respectively. $e_{i}$ is the elasticity of output with respect to the relevant independent variable in equation (2). Equation (4) argues that the greater the openness of the trade regime, the faster the growth because of faster adoption and expansion of technology allowing for changes in capital stock, labor force and human capital. The contention is derived from the 'new' growth theories. The existing measures of openness include: share and growth of exports and imports in GDP, the black market exchange rate premium, the dollar index of outward orientation, the Halevi-Thomas index of trade liberalization, and the index of relative price of tradeables (Note 6). We used trade share and growth of exports and imports in GDP. Our decision is influenced by the absence of consistent data on other measures of openness and inadequate relevance of other measures such as Learner index and black market exchange rate premium.

For the purpose of estimation, equations (2) and (4) are stated in a more flexible form with a consistent term as:

$$
\log Y=\beta_{0}+\beta_{1} \log K+\beta_{2} \log L+\beta_{3} \log H+\beta_{4} \log T_{0}+\varepsilon_{t}
$$

where $\mathrm{Y}$ represents per capita GDP, $\mathrm{K}$ is the ratio of investment to GDP, L denotes the labour force as a share of population. Following Mankiw, Romer and Weil (1992), H measures human capital investment in terms of schooling (high school investment ratio) and $\mathrm{T}_{\mathrm{o}}$ the trade openness indicator. Our a priori expectation is that $\beta_{1}>0$, $\beta_{2}>0, \beta_{3}>0$, and $\beta_{4}>0$

Prior to testing for cointegration, the time series of the data used in the model are first tested for stationarity using the Augmented Dickey Fuller [1979, 1981] (ADF) and Phillips-Perron (PP) techniques. The ADF tests are based on the following model:

$$
\Delta X_{t}=\alpha+\beta X_{t-1}+\sum_{j=1}^{p} \gamma_{j} \Delta X_{t-j}+\varepsilon_{t}
$$

where $\Delta$ is the difference operator, $\mathrm{X}$ consists of each of the five variables in the model, $\mathrm{t}=1, \ldots \ldots . \mathrm{T}$, is an index of time, $\Delta X_{t-j}$ is the lagged first differences to accommodate serial correlation in errors, $\varepsilon_{t}$ the error term. When tstatistics are less than the critical values, the null hypothesis of the unit root $(\beta=0)$ cannot be rejected. However, if the $t$ ratio is larger than the critical value, the null hypothesis of non-stationarity can be rejected. We selected the appropriate lag length using the Akaike Information Criterion (AIC) and Schwartz Bayesian Criterion (SBC). In order to account for the dynamics of the model (equation), an error correction model (ECM) is specified in the first difference as follows: 


$$
\begin{aligned}
& \Delta \ln Y_{t}=\beta_{0}+\sum_{t=1}^{n} \beta_{1 i} \Delta \ln Y_{t-i}+\sum_{i=0}^{n} \beta_{2 i} \Delta K_{t-1}+\sum_{i=0}^{n} \beta_{3 i} \Delta L_{t-i}+\sum_{i=0}^{n} \beta_{4 i} \Delta H_{t-i} \\
& +\sum_{i=0}^{n} \beta_{5 i} \Delta T_{0 t-i}+\beta_{6} E C_{t-1}+\varepsilon_{t}
\end{aligned}
$$

where $E C_{t-1}$ is the lagged value of the long run error term (equation 7) and $\beta_{6}$ is the error correction coefficient. 4.1 Sources of Data

We used quarterly time series data from 1980:Q1 to 2008:Q4. The data used are obtained from Banco de Mexico; the International Financial Statistics, a publication of the International Monetary Fund (IMF) and the Economic Indicators published by the World Bank (see appendix for the definitions and measurements of variables).

\section{Empirical Results}

We used ADF and PP tests to analyze the time series properties of the data. Our results show that the null hypothesis of the non-stationarity cannot be rejected. In other words, the variables are non-stationary in levels as shown in Table 3.

\section{Insert Table 3}

As all the variables in the model are found to be I(1), we conduct Johansen-Juselius cointegration analysis. Of course, testing for cointegration enables us to detect whether a stable long run relationship exists among the variables. Johansen (1988) and Johansen and Juselius (1990) provide a detailed description of the test procedure. A VAR containing three lags (this implies a lag length of two in the VEC model) was chosen as the best system to test for cointegration (Note 7).

\section{Insert Table 4}

The result of the Johansen cointegration test (Table 4) suggests that it is possible to reject the null hypothesis of no cointegration as both the trace and maximum eigenvalue statistics indicate 1 cointegrating vector at 5 percent significant level. Our result implies that there exists a long run relationship among the variables. When normalized for a unit coefficient on LY (table 5), the cointegrating regression on economic growth is given as:

\section{Insert Table 5}

From Table 5, only two of the coefficients of the explanatory variables of economic growth are found to be greater than or almost unity, thus indicating high responsiveness of economic growth to changes in these variables (.i.e. the coefficients' estimates of $\mathrm{K}$ and $T_{0}$ in the equilibrium relation are significant at 5 percent level and have the expected signs). Our findings revealed that capital (investment) and trade openness are the main determinants of economic growth in Mexico.

On the other hand, L and $\mathrm{H}$ have the expected sign but contrary to our expectation, their coefficients are low and insignificant at 5 percent. Although, the Mexican educational system witnessed various reforms in the 1990s and 2000s (Note 8), and the 2006 World Bank report claimed that "Mexico has made great strides in improving access to education and literacy rates over the past few decades", our results imply that more needs to be done if its impact is to be felt on growth. The enrolment at both the primary and secondary levels have improved and more children are completing primary education, the average year of school for the population 15 years and over (secondary) was around 8 years during the $2005-2006$ school year, a marked improvement on a decade earlier when it was 6.8 years, but still very low compared to other OECD countries. Using Municipio (county) data from 1990 - 2000, Helper, Levine and Woodruff (2006) found that liberalization created incentives for Mexico to increase its investment in education but the current findings suggest that the investment is inadequate (Note 9).

Following Enders (2004), we estimate the error correction model (ECM). The ECM permits the introduction of past disequilibrium as an explanatory variable in the dynamic behavior of existing variables and thus facilitates capturing both the short run dynamics and long run relationship among variables. The larger the coefficient of $E C_{t-1}$ is, the greater the response of economic growth to the previous period's deviation from long run equilibrium. On the other hand, a very small coefficient of the error correction term implies that economic growth is unresponsive to the previous period's equilibrium error.

\section{Insert Table 6}

The error correction coefficient estimated at -0.206 is statistically significant and with the correct sign (negative) at the 5 percent level. This suggests that the system corrects its previous period's disequilibrium by 20 percent a 
quarter. Diagnostic tests indicate no evidence of misspecification, no presence of serial correlation, normality, and heteroscedasticity among others in the residuals.

\section{Conclusion}

This paper examined whether trade liberalization will lead to long run economic growth in Mexico. We employed the Johansen cointegration techniques and error correction method using quarterly data from 1980:q1 to 2008:q4.

Our results shows that long run economic growth in Mexico is largely explained by openness (trade liberalization), and the level of capital (investment). The results, however, show that the contribution of labor force and human capital to the Mexican economy is minimal. This is seemingly surprising given increased school enrolment and educational spending by more than 2 percent of the gross domestic product over the last decade. The estimated coefficient of the ECM indicates low speed of adjustment to equilibrium. The sign of the ECM term is negative and significant, thus, confirming that the system corrects its previous period's disequilibrium by 20 percent a quarter.

The policy implication of our results is that Mexico needs to intensify trade and investment reforms to promote sustainable long run economic growth. As an open economy, Mexico should continue to avoid real exchange rate overvaluation while minimizing exchange rate volatility. There is also the need to complement reforms in trade and investment sectors with reforms in education sector. Investing in more and better-distributed education in the labor force helps create conditions that are conducive to higher productivity and sustainable growth. Mexico also needs to create diversified, dynamic and competitive sectors capable of absorbing the more educated labor force to translate human capital to higher economic growth.

\section{References}

Bank of Mexico (Banco de Mexico). Estadisticas [online]. Available from: www.banxico.org.mx [Accessed 27 November 2009 and 18 December 2010].

Balassa, Bela. (1970). The Economic Reform in Hungary. Economica, New Series, Vol. 37, No. 145, pp 1-22.

Balassa, B. (1971). The Structure of Protection in Developing Countries. Johns Hopkins University Press

Balassa, Bela. (1982). Development Strategies and Economic Performance: A Comparative Analysis of Eleven Semi-industrialized Economies. In Balassa Bela, ed., Development Strategies in Semi-industrialized Economies, Baltimore, MD: Johns Hopkins University Press, 38-62.

Bhagwati, J. (1978). Foreign Trade Regimes and Economic Development: Anatomy and Consequences of Exchange Control Regimes, Cambridge, MA: Ballinger.

Collier, P. (1993). Higgledy-piggledy liberalization, The World Economy 16: 503-512.

Dollar, D. (1992). Outward-Oriented Developing Economies Really Do Grow More Rapidly: Evidence from 95 LDCs, 1976-1985, Economic Development and Cultural Change, 40(3): 523-44.

Dollar, D. and A. Kraay. (2001). Trade, Growth and Poverty, World Bank Policy Research Department Working Paper No. 2587, Washington DC

Dollar, D. and A. Kraay. (2002). Growth is Good for the Poor. Journal of Economic Growth, Vol. 7, pp 195-225.

Dutt, S., D. and Ghosh, D. (1996). The Export Growth-Economic Growth Nexus: A Causality Analysis, Journal of Developing Areas, Vol:30, No:2, pp.167-182

Edwards, S. (1989). Temporary Terms-of-Trade disturbances, the Real Exchange rate and the Current Account, Economica, 56, pp 343-357

Edwards, S. (1993). Openness, Trade Liberalization and Growth in Developing Countries, Journal of Economic Literature, Vol. 31, pp 1358-1393.

Enders, Walter. (2004). Applied Econometric Time Series, New York: John Wiley \& Sons, Inc.

Ghatak, S., C. Milner and U. Utkulu. (1995). Trade Liberalization and Endogenous Growth: Some Evidence for Turkey, Economics of Planning, 28, 147-67.

Greenaway D, Morgan W and Wright P. (1998). Trade reform, adjustment and growth: What Does the Evidence tell Us. Economic Journal 108(450):1547-1561, September

Grossman, G. M. and Helpman, E. (1991). Quality Ladders and Product Cycles, Quarterly Journal of' Economics, 106

Hanson, Gordon and Harrison, Anne. (1999). Trade, Technology, and Wage Inequality, Industrial and Labor Relations Review 52(2). January, 271-88. 
Helpman, E. and P. Krugman, (1989). Trade Policy and Market Structure, (Cambridge, MA, and London, The MIT Press.

International Monetary Fund (IMF). International Financial Statistics CD- ROM.

Instituto Nacional de Geografia e Informatica (INEGI)., Mexico, 2009.

Johansen, S. (1988). Statistical Analysis of Cointegrating Vectors. Journal of Economic Dynamics and Control, Vol. 12 , pp $213-254$.

Johansen and K. Juselius. (1990). Maximum Likelihood Estimation and Inference on Cointegration with Applications to the Demand for Money, Oxford Bulletin of Economics and Statistics, 52: 169-210

Krishn A, K.; Ozyildirim, A.; Swanson, N. R. (2003). Trade, investment and growth: nexus, analysis and prognosis. Journal of Development Economics, v. 70, p. 479-499.

Krueger, A. (1978). Liberalization Attempts and Consequences, Cambridge: Ballinger

Krugman, P. (1986). (Ed.). Strategic Trade Policy and the New International Economics, Cambridge, MA: The MIT Press.

Little, Ian, T. Scitovsky and M. Scott. (1970). Industry and Trade in Some Developing Countries A Comparative Study, Cambridge: Oxford University Press.

Mankiw, N. G., D. Romer and D. N. Weil. (1992). A Contribution to the Empirics of Economic Growth, Quarterly Journal of Economics, 107: 407-437

Martin, K. M. (1992). Openness and Economic performance in sub-Saharan Africa: Evidence from time series cross country analysis. Working Paper 2025, World Bank, Washington DC

Miankhel, A. K Thangavelu, S and Kalirajan, K. (2009). On Modeling and Measuring Potential Trade, Paper presented at the $4^{\text {th }}$ Annual International Conference on Public Policy and Management, Bangalore, (IIMB).

Moreno-Brid, J. C et al. (2005). Mexico: Economic Growth, Export and Industrial Performance after NAFTA. CEPAL, Economic Development Unit, December.

Myrdal G. (1957). Rich Lands and Poor, Harper and Row, New York

Papageorgiou, D., Choksi, A. \& Michaely, M. (1990). Liberalization of foreign trade in developing countries: The lessons of Experience, World Bank, Washington, DC.

Pastor. (1994). Collective Responses to Regional Problems: The Case of Latin America and the Caribbean. Cambridge, Mass: Committee on International Security Studies,

Phillips, P and Perron, P. (1988). Testing for Unit Roots Time Series Regression, Biometrika

Perron, P. (1988). Trends and Random walks in Macroeconomic Time Series, Journal of Economic Dynamics and Control, Vol. 12, pp 297-332

Phillips, P. (1987). Time Series Regression with a Unit Root. Econometrica, Vol. 55, pp 277-301.

Prebisch, R. (1950). The Economic Development of Latin America and its Principal Problems, Economic Bulletin for Latin America, 7(1):1-22, February 1962 (reprinted).

Rodríguez, F. and D. Rodrik. (2001). Trade Policy and Economic Growth: A Skeptic's Guide to the Cross-National Evidence, Macroeconomics Annual 2000, Ben Bernanke and Kenneth S. Rogoff (eds.). MIT Press for NBER, Cambridge, MA.

Romer, P. M. (1990). Endogenous Technological Change, Journal of Political Economy, 98: S71-S102

Romer, P. M. (1993). Idea Gaps and Object Gaps in Economic Development, Journal of Monetary Economics, 32 : 543-73

Romer, P. M. (1994). The origins of endogenous growth, Journal of Economic Perspectives 8(1): 3-22.

Sachs, J. and A. Warner. (1995). Economic reform and the process of global integration, Brookings Papers on Economic Ac

Sachs, J.D. and A.M. Warner. (1995). Economic Reform and the Process of Global Integration, Brookings Papers on Economic Activity, Vol. 1, pp. 1-118.

Salinas, G and Aksoy, A. (2006). Growth Before and After Trade Liberalization. World Bank Policy Research Working Paper 4062 
Singer, H.W. (1950). The Distribution of Gains between the Investing and Borrowing Countries, American Economic Review, 40(2).

Srinivasan, T.N. (2001). Trade, Development and Growth, Princeton Essays in International Economics No.225, International Economics Department, Princeton University.

Streenten, P. (1971). Review of Little, et al., Economic Journal, Vol. 81, No 1, pp 144-48, March.

Ten Kate, Adriaan (1992). Trade Liberalization and Economic Stabilization in Mexico: Lessons of Experience World Development 20(5)., 659-672.

World Bank (1989). Sub-Sahara Africa: From Crisis to Sustainable Growth. Washington DC, The World Bank

World Bank (1990). Making Adjustment Work for the Poor: A Framework for Policy Reform in Africa, World Bank Study, Washington DC, The World Bank, September

World Bank (1993). The East Asian Miracle: Economic Growth and Public Policy, Oxford University Press, September

World Bank (2007). International Trade and Climate Change: Economic, Legal and Institutional Perspectives, World Bank, Washington DC.

\section{Notes}

Note 1. A maquiladora is an operation that involves manufacturing in a country that is not the client's and as such has an interesting duty or tariff treatment. It entails a factor that import material and equipment on a duty and tariff free basis for assembly and then re-exports the assembled or manufactured products.

Note 2. Article 102 of the agreement formally identifies NAFTA's main objectives: to "eliminate barriers to trade in, and facilitate the cross-border movement of, goods and services between the territories of the parties; promote conditions to fair competition in the free trade area; increase substantially investment opportunities in the territories of the parties; provide adequate and effective protection and enforcement of intellectual property rights in each party's territory", (NAFTA, 1994).

Note 3. The parentheses show the dates that the free trade agreements with the respective countries came into force.

Note 4. The percentages represent gross exports but not the value added of the Maquiladoras industry. Information obtained from the Instituto Nacional de Geografia e Informatica (INEGI), Mexico, 2009.

Note 5. Empirically, this equality relates to average incentives for import substitutes and exports.

Note 6. The conceptualization and problems associated with these measures are discussed in Harrison (1991) and Martin (1992).

Note 7. The results of these diagnostic tests are available upon request.

Note 8. Some of these measures include oportunidades (formerly known as PROGRESA) which provides cash grants to low income families so that their children can attend school and obtain health services; Enciclomedia digitalizes the school curriculum into CD-ROMs so that students can learn interactively with the aid of computers; quality school program which targets low performing schools; and a wide range of compensatory programs aimed at improving infrastructure, equipment, and materials and proving incentives to teachers and school principals in order to decrease teacher absenteeism and improve school supervision functions.

Note 9. Mexico increased education spending by more than 2 percent of GDP in the last decade. 
Table 1. Mexico's and Global Export of Manufactured Products

Panel A: Mexico's share of Exports of Manufactured in the World (Top 10 countries) 1985-1994 \& 1994-2004

\begin{tabular}{|l|l|l|l|l|l|l|l|l|}
\hline & $\mathbf{1 9 8 5}$ & $\mathbf{1 9 9 4}$ & $\begin{array}{l}\text { Diff }^{a} \mathbf{:} \\
\mathbf{1 9 8 5 - 9 4}\end{array}$ & Rank & & $\mathbf{1 9 9 4}$ & $\mathbf{2 0 0 4}$ & $\begin{array}{l}\text { Diff }^{a}: \\
\mathbf{1 9 9 4 - 0 4}\end{array}$ \\
\hline China & 1.42 & 5.86 & 4.44 & 1 & China & 5.86 & 10.22 & 4.36 \\
\hline Malaysia & 0.55 & 1.73 & 1.18 & 2 & Mexico & 1.71 & 3.96 & 2.25 \\
\hline Singapore & 0.88 & 1.88 & 1.00 & 3 & Philippines & 0.43 & 1.02 & 0.59 \\
\hline Thailand & 0.30 & 1.06 & 0.77 & 4 & Malaysia & 1.73 & 2.31 & 0.58 \\
\hline Mexico & 1.01 & 1.71 & 0.70 & 5 & Hungary & 0.23 & 0.74 & 0.51 \\
\hline USA & 12.82 & 13.36 & 0.55 & 6 & Thailand & 0.31 & 0.77 & 0.46 \\
\hline Indonesia & 0.19 & 0.67 & 0.48 & 7 & Turkey & 0.40 & 0.71 & 0.31 \\
\hline Spain & 1.49 & 1.79 & 0.30 & 8 & Poland & 0.40 & 0.62 & 0.22 \\
\hline Poland & 0.18 & 0.40 & 0.22 & 9 & Indonesia & 1.06 & 1.27 & 0.21 \\
\hline India & 0.47 & 0.67 & 0.20 & 10 & Isreal & 0.41 & 0.61 & 0.20 \\
\hline
\end{tabular}

Source: Moreno-Brid et al (2005) and author's calculations based on ECLAC, CAN 2008 and 2009. Manufactures cover items 6, 7, and 8 of the CAN classification

Note (a): 'Diff' means difference

Panel B: Mexico's share of Total Value of Exports of Manufactures in the World (Top 10 countries) 1985-1994 \& 1994-2004 (millions of dollars)

\begin{tabular}{|l|l|l|l|l|l|l|l|l|}
\hline & $\mathbf{1 9 8 5}$ & $\mathbf{1 9 9 4}$ & $\begin{array}{l}\text { Diff }^{a} \mathbf{:} \\
\mathbf{1 9 8 5 - 9 4}\end{array}$ & Rank & & $\mathbf{1 9 9 4}$ & $\mathbf{2 0 0 4}$ & $\begin{array}{l}\text { Diff }^{a}: \\
\mathbf{1 9 9 4 - 0 4}\end{array}$ \\
\hline US & 121.0 & 355.0 & 234.0 & 1 & China & 155.0 & 387.2 & 231.4 \\
\hline China & 13.4 & 155.8 & 142.4 & 2 & US & 355.0 & 502.7 & 147.7 \\
\hline France & 54.9 & 139.1 & 84.2 & 3 & Germany & 277.3 & 364.2 & 86.9 \\
\hline Italy & 54.8 & 131.4 & 76.6 & 4 & Mexico & 45.4 & 137.5 & 92.1 \\
\hline UK & 45.7 & 118.7 & 73.0 & 5 & France & 139.1 & 181.2 & 42.1 \\
\hline Canada & 47.0 & 100.5 & 53.5 & 6 & Malaysia & 46.0 & 80.2 & 34.2 \\
\hline Singapore & 8.3 & 49.9 & 41.6 & 7 & Netherlands & 59.9 & 87.7 & 28.2 \\
\hline Belgium & 34.0 & 75.0 & 41.0 & 8 & Philippines & 11.5 & 38.5 & 27.0 \\
\hline Malaysia & 5.2 & 46.0 & 40.8 & 9 & Thailand & 28.3 & 49.9 & 21.6 \\
\hline Mexico & 9.6 & 45.4 & 35.9 & 10 & Hungary & 6.3 & 26.8 & 20.5 \\
\hline
\end{tabular}

Sources: Moreno-Brid et al (2005) and author's calculations based on ECLAC, CAN 2008 and 2009

Note (a): 'Diff' means difference

Table 2: Market share of Exports and Imports by FTA partner

\begin{tabular}{|c|c|c|c|c|c|c|c|}
\hline & 1996 & 1998 & 2000 & 20002 & 2004 & 2006 & 2008 \\
\hline \multicolumn{8}{|c|}{ Panel A: Market share of Mexico's Exports } \\
\hline NAFTA & $85 \%$ & $88 \%$ & $90 \%$ & $90 \%$ & $89 \%$ & $87 \%$ & $83 \%$ \\
\hline EU & $4 \%$ & $3 \%$ & $3 \%$ & $3 \%$ & $4 \%$ & $4 \%$ & $6 \%$ \\
\hline Japan & $1 \%$ & $0 \%$ & $1 \%$ & $1 \%$ & $1 \%$ & $1 \%$ & $1 \%$ \\
\hline Chile & $1 \%$ & $1 \%$ & $0 \%$ & $0 \%$ & $0 \%$ & $0 \%$ & $1 \%$ \\
\hline Other FTA partners & $1 \%$ & $1 \%$ & $1 \%$ & $1 \%$ & $1 \%$ & $1 \%$ & $1 \%$ \\
\hline Rest of World & $8 \%$ & $6 \%$ & $4 \%$ & $5 \%$ & $5 \%$ & $7 \%$ & $9 \%$ \\
\hline \multicolumn{8}{|c|}{ Panel B: Market share of Mexico's Imports } \\
\hline NAFTA & $77 \%$ & $76 \%$ & $75 \%$ & $66 \%$ & $62 \%$ & $54 \%$ & $52 \%$ \\
\hline $\mathrm{EU}$ & $9 \%$ & $9 \%$ & $9 \%$ & $10 \%$ & $12 \%$ & $11 \%$ & $13 \%$ \\
\hline Japan & $5 \%$ & $4 \%$ & $4 \%$ & $6 \%$ & $6 \%$ & $6 \%$ & $5 \%$ \\
\hline Chile & $0 \%$ & $0 \%$ & $1 \%$ & $1 \%$ & $1 \%$ & $1 \%$ & $1 \%$ \\
\hline Other FTA partners & $1 \%$ & $1 \%$ & $0 \%$ & $2 \%$ & $2 \%$ & $2 \%$ & $2 \%$ \\
\hline Rest of World & $8 \%$ & $9 \%$ & $11 \%$ & $17 \%$ & $24 \%$ & $27 \%$ & $28 \%$ \\
\hline
\end{tabular}

Source: Author's calculations based on ECLAC, CAN 2008, 2009 and 2010 
Table 3. Unit Root Tests for Stationarity

\begin{tabular}{|c|c|c|c|c|c|c|}
\hline \multirow[b]{2}{*}{ Variables } & \multirow[b]{2}{*}{ Level/ First Difference } & \multicolumn{2}{|c|}{ ADF Tests Statistic } & \multicolumn{2}{|c|}{ PP Tests Statistic } & \multirow[b]{2}{*}{ Conclusion } \\
\hline & & $\begin{array}{l}\text { Without } \\
\text { Trend }\end{array}$ & $\begin{array}{l}\text { With } \\
\text { Trend }\end{array}$ & $\begin{array}{l}\text { Without } \\
\text { Trend }\end{array}$ & $\begin{array}{l}\text { With } \\
\text { Trend }\end{array}$ & \\
\hline \multirow{2}{*}{ LY } & Level & -0.77 & -2.73 & -1.64 & -2.78 & \multirow{2}{*}{$\mathrm{I}(1)$} \\
\hline & $1^{\text {st }}$ Difference & $-4.63 *$ & $-4.01 *$ & $-22.18 *$ & $-22.20 *$ & \\
\hline \multirow{2}{*}{ LK } & Level & -1.01 & -2.86 & -2.27 & -2.48 & \multirow{2}{*}{$\mathrm{I}(1)$} \\
\hline & $1^{\text {st }}$ Difference & $-5.63 *$ & $-5.61 *$ & $-11.11 *$ & $-11.08 *$ & \\
\hline \multirow{2}{*}{$\mathrm{LT}_{0}$} & Level & -2.31 & -2.15 & -1.98 & -1.61 & \multirow{2}{*}{$\mathrm{I}(1)$} \\
\hline & $1^{\text {st }}$ Difference & $-4.48^{*}$ & $-4.86^{*}$ & $-15.63^{*}$ & $-15.99 *$ & \\
\hline \multirow{2}{*}{ LH } & Level & -1.05 & -2.97 & -1.22 & -2.59 & \multirow{2}{*}{$\mathrm{I}(1)$} \\
\hline & $1^{\text {st }}$ Difference & $-6.79 *$ & $-6.77 *$ & $-12.31 *$ & $-12.28 *$ & \\
\hline \multirow{2}{*}{ LL } & Level & -0.01 & -1.06 & 0.13 & -0.92 & \multirow{2}{*}{$\mathrm{I}(1)$} \\
\hline & $1^{\text {st }}$ Difference & $-6.70 *$ & $-6.87 *$ & $-6.80 *$ & $-6.90 *$ & \\
\hline
\end{tabular}

Note: Unit root tests are performed using Eviews $7,{ }^{*}$ denotes significance at the 5 percent level. Numbers in the Table are the pseudo t- statistics for testing the null hypothesis that the series is non-stationary. The critical values of the ADF and PP statistics with a constant but no trend are $-3.47,-2.88$, and -2.57 at the 1,5 and 10 percent levels while tests statistics with a constant and trend are $-4.01,-3.43$, and -3.14 at the 1,5 and 10 percent levels.

Table 4. Johansen - Juselius Maximum Likelihood Cointegration Test

\begin{tabular}{|c|c|c|c|c|}
\hline Null & Alternative & Trace Statistic & & $5 \%$ Critical Value \\
\hline \multicolumn{5}{|c|}{ Panel (A) Unrestricted Cointegration Rank Test (Trace Test) } \\
\hline$r=0$ & $r=1$ & $78.99 *$ & 69.81 & \\
\hline$r \leq 1$ & $r=2$ & 36.98 & 47.86 & \\
\hline \multicolumn{5}{|c|}{ Panel (B) Unrestricted Cointegration Rank Test (Maximal Eigenvalue Test) } \\
\hline$r=0$ & $r=1$ & $42.01 *$ & 33.87 & \\
\hline$r \leq 1$ & $r=2$ & 18.31 & 27.58 & \\
\hline
\end{tabular}

Note: $r$ indicates the number of cointegrating vector(s) and $*$ denotes the rejection of null hypothesis of no cointegration at 5 percent significance level.

Table 5. Estimates of Long Run Cointegration Vector

\begin{tabular}{|lcccc|}
\hline$L Y$ & $L K$ & $L L$ & $L H$ & $L T_{0}$ \\
1.00 & 0.834 & 0.156 & 0.062 & 1.049 \\
& $(0.246)$ & $(0.121)$ & $(0.053)$ & $(0.248)$ \\
\hline
\end{tabular}

Note: Figures in parentheses indicate standard errors. 
Table 6. Estimated Error Correction Model

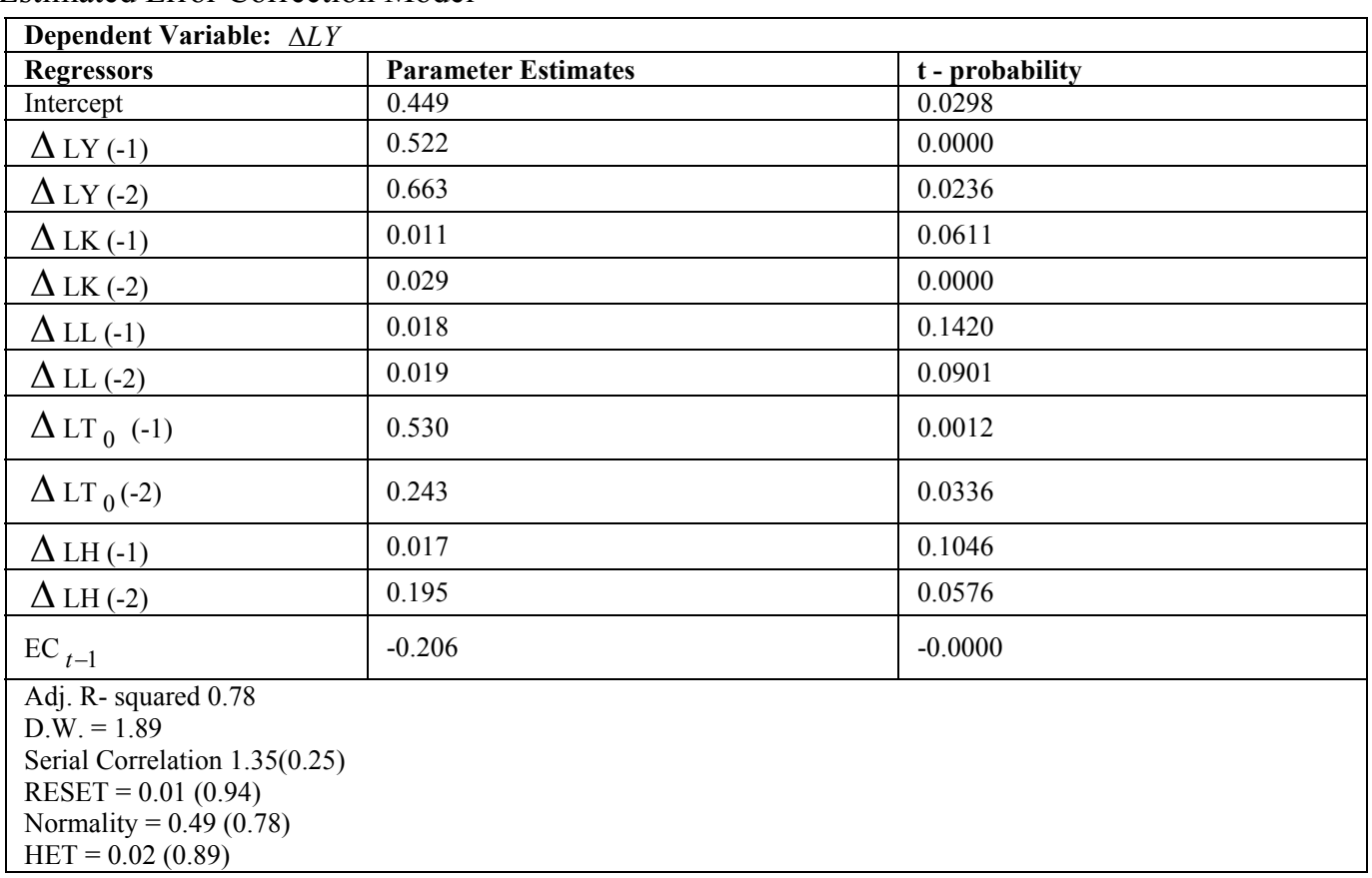

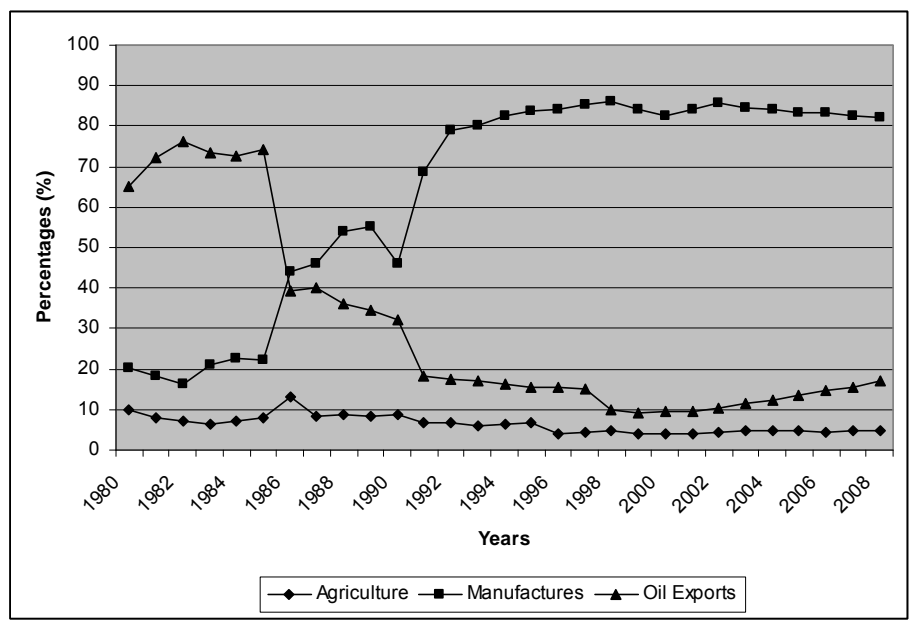

Figure 1. Mexico's Composition of Total Exports $1980-2008$

Definition and Measurement of variables

\begin{tabular}{|l|l|l|}
\hline Variable & Definition of the variable & \multicolumn{1}{c|}{ Measurement } \\
\hline K & Capital & Gross investment as a share of GDP \\
\hline L & Labour force & Labour force as a share of population \\
\hline H & Human Capital & Secondary enrolment \\
\hline To & Trade Liberalization (openness indicator) & Trade share and growth of exports and imports in GDP \\
\hline Y & Income (Output) & Per capita GDP at 1995 prices \\
\hline T & Time Trend & $1980: 1-2008: 4$ \\
\hline
\end{tabular}

